宿題報告：

\title{
農業生産活動における化学物質の人体への影響に 関する研究
}

\author{
松下 敏 夫 \\ (鹿児島大学医学部教授)
}

$$
\text { は じめに }
$$

わが国に和ける有効登録農薬件数は6,084件(有効成 分数約 370 種）（昭和 63 年 9 月 30 日現在）といらように きわめて多く，またそれら化学物質の農業生産活動に 伴ら人体への影響も, 直接これを取り扱ら農業従事者 への急性および慢性的影響と, 環境污染に伴う人体影 響など多岐にわたる。そこで，ここでは昭和 61 年から 3 年間にわたって行なわれた「農業生産活動における 化学物質の人体への影響に関する研究」の研究班活動 の研究成績を中心にして，これに若干の考察を加えた い。な打研究班の構成は, 表 1 のごとくである。

\section{1. 農業化学物質による中毒・障害例の解明 とその予防対策に関する研究}

農業生産の向上の面に括いて農業化学物質の果たし てきた役割はきわめて大きいものの，他方では，その 使用, 保管, 運搬の過程に打ける事故や健康障害の発 生も後を断たないのが現状である。因みに, 厚生省の 人口動態統計の成績から，農薬使用による死亡状況の 推移をらかがうと, 近年, 年々増加して1986年（昭和

表 1 . 農業生産活動における化学物質の人体へ の影響に関する研究 (昭和61年〜 63年) の研究班の構成

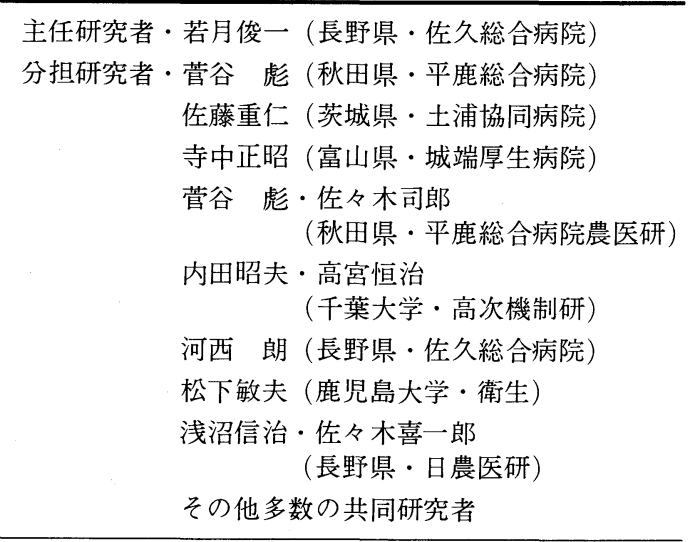

61年)の 2,631 人がピークになっている。この内訳は主 として用途外使用 (自殺) によるもので, その使用農 薬の種類は，有機燐剤やカーバメート剂は横這いであ るが，その他の農薬が増加して扣り，その大部分(95\% 程度) はパラコート㓮によるものとみなされている。 しかし, これらの数字は, 農薬による健康障害の氷山 の一角を示すのにすぎない。

歴史的にみると, 1939年に Müller が DDT に殺虫作 用があることを明らかにして以来，次々と新しい合成 農薬が開発され，農業生産やマラリア撲殺対策などに 大きな成果を上げた。しかし，1960年頃からはそのマ イナスの側面もしだいに問題視されるよらになった (表 2 )。

（1）農薬中毒 (障害) 臨㦿例全国調查

上記の国際的な動向に対応して, 日本農村医学会で も, その創立の当初から, 農薬による健康障害とその 予防についての多くの研究が行なわれてきた。とくに 1970年（昭和45年）からは，農薬による健康障害の問 題点を把握することを目的に，若月・松島・菅谷らを 中心にして, 全国の会員から報告された農薬中毒（障 害) 臨床例の集計を行なってきている。これは, 所定

表 2 、農薬をめぐる歩み

\begin{tabular}{|c|c|}
\hline 1939 & DDT の殺虫効果発見（Müller） \\
\hline 1942 & $\gamma-$ BHC の殺虫効果発見 (Slade ら) \\
\hline 1962 & $\begin{array}{l}\text { Carson“Silent Spring”刊行 } \\
\text { 農薬の残留毒性問題化（WHO） }\end{array}$ \\
\hline 1967 & 農林省パラチオン, TEPP剤69年末生産中止通達 \\
\hline 1969 & DDT など有機塩素系殺虫剤の規制始まる \\
\hline 1970 & $\begin{array}{l}\mathrm{DDT}, \mathrm{BHC} \text { 使用禁止 } \\
\text { 日本農村医学会農薬中毒臨床例全国調査開始 }\end{array}$ \\
\hline 1971 & 農薬取締法改正, 環境庁発足 \\
\hline 1972 & PCB 使用禁止 \\
\hline 1986 & $\begin{array}{l}\text { クロルデン製造販売使用禁止 } \\
\text { パラコート・ジクワット複合剤発売 }\end{array}$ \\
\hline
\end{tabular}


の農薬中毒臨床例調査票を用いて，医療機関を受診し た症例を収集しており，なた農薬中毒の定義について は広義に解釈して, 急性・慢性中毒, 皮膚・外眼部・ 鼻咽喉・呼吸器障害, 農薬アレルギー, 誤飲・誤用, 自（他）殺および未遂など，農薬に関連する健康障害 のすべてを含むこととしている。

まずこれらすべての臨床例を年令階級別にみると， 一般に低年令層から高令者層末で広く分布している が, 50〜 59才が最も多く, 約30\%を占めている。また, 障害発生を月別にみると, 農薬散布が盛んな 6 月に ピークがあり，5月から 8 月までの 4 か月間が約 $62 \%$ と過半数を占めている。

そこで，これら臨床例を発生原因別にみると，散布 中の障害例が約 3 割, 散布外および誤飲・誤用がそれ ぞれ $6 \%$ 前後である(表 3 )。一方, 全年令にわたって 最も多いのが自殺およびその未遂によるもので，約 6 割を占めている。季節的にみると，一般に散布中の症 例は 5 月から 9 月に集中する傾向があり，11月から 2 月の冬期は，自殺执よび未遂例が多いという傾向が認 められる。

つぎに, 疾患別にみると, 調査を開始した年から今 日まで，常に急性中毒が第 1 位を占め，とくに1986年 から1988年の 3 年間ではその割合がさらに大きくな り，8 割近くを占めてている。急性中毒に次いで多い

表 3．性別原因別農薬中毒（障害）臨床例 (1986 88年)

\begin{tabular}{|c|c|c|c|c|}
\hline 原 因 & 男 子 & 女子 & \multicolumn{2}{|c|}{ 計 } \\
\hline 散 布 中 & 94 & 51 & 145 & $(29.5)$ \\
\hline 散 布 外 & 13 & 15 & 28 & $(5.7)$ \\
\hline 誤飲・詔用 & 24 & 8 & 32 & $(6.5)$ \\
\hline 自殺及び未遂 & 142 & 140 & 282 & $(57.4)$ \\
\hline 不 & 2 & 2 & 4 & $(0.8)$ \\
\hline 計 & 275 & 216 & 491 & $(100.0)$ \\
\hline
\end{tabular}

表 4 ．疾患別農薬中毒 (障害) 臨床例 $($ 菅谷·他)

\begin{tabular}{crrrr}
\hline 疾 患 & $1970-1979$ & $1980-1985$ & $1986-1988$ \\
\hline 急性中毒 & $824(48.3)$ & $479(64.6)$ & $382(77.8)$ \\
皮膚障害 & $682(39.9)$ & $238(32.1)$ & $96(19.6)$ \\
眼 障 害 & $90(5.3)$ & $15(2.0)$ & $9(1.8)$ \\
鼻・咽喉障害* & $16(0.9)$ & $10(1.3)$ & $3(0.6)$ \\
その他 & $95(5.6)$ & $0(0)$ & $1(0.2)$ \\
\hline 計 & $1,707(100.0)$ & $742(100.0)$ & $491(100.0)$ \\
注：（）内\%，*気管障害を含む
\end{tabular}

のが皮膚障害であるが，以前に比べると相対的にやや 少なくなっている。他方, 眼障害や鼻咽喉・呼吸器系 障害なども若干報告され，臨床的診断が比較的容易な これらの疾患が一般に把握されているといえる（表 4 )。しかしながら，その存在が十分考えられる慢性中 毒の臨床例は，ほとんど報告されていないのが現状で ある。

つぎに農薬の種類別にみると，有機燐剤が約 4 分の 1 を占めているが，とくに除草剤の割合が1986年から 88年の間では $43.4 \%$ と著増していることが注目され る(表 5 )。このらち約 9 割はパラコート系農薬による ものである。これを農薬の種類と疾患との関係でみる と，急性中毒（障害）の原因農薬としては，圧倒的に 除草剂(パラコート剂)が多く，これに有機燐剤，カー バメート剂が続いている。他方，皮膚障害で目立つの は有機塩素剤と硫黄剤である。また, 発生原因を農薬 の種類との関係でみると, 散布中に障害を生じた症例 では, カーバメート剂, 有機塩素剂, 除草剂, 硫黄剤 が多く，自殺扣よび自殺未遂では，除草剂と有機燐剂 によるものが多い傾向が認められる。

（2） パラコート剂中毒患者の解明と農薬保管状況等の 調查

ビピリジウム系除草剤であるパラコートは, 大量に 体内に侵入すると, その急性毒性として, 第 1 にショッ ク, 第 2 に循環不全(急性腎不全), 第 3 に呼吸不全(肺 緎維症）といった劇的な症状を起こすが, 現在のとこ ろ特効薬は見出されて扣らず，多くの場合致死的な転 㷌をとる。そこで，1985年に長野で開催された第34回 日本農村医学会総会では, 大きな社会問題にもなって いたパラコート剤による農薬中毒の多発に対して, パ

表 5. 農薬種類別農薬中毒 (障害) 臨床例 (菅谷・他)

)内: \%

\begin{tabular}{|c|c|c|c|}
\hline 農＼cjkstart薬 & $1970-1979$ & $1980-1985$ & $1986-198$ \\
\hline \multirow{2}{*}{ 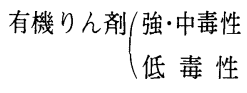 } & $263(15.4)$ & $78(10.5)$ & $62(12.6)$ \\
\hline & $253(14.8)$ & $101(13.6)$ & $65(13.2)$ \\
\hline 有機塩素剤 & $100(5.9)$ & $46(6.2)$ & $18(3.7)$ \\
\hline カーバメイト剤 & $77(4.5)$ & $24(3.2)$ & $19(3.9)$ \\
\hline 抗生物質剤 & $42(2.5)$ & $14(1.9)$ & $3(0.6)$ \\
\hline 除 草 剤 & $212(12.4)$ & $211(28.4)$ & $213(43.4)$ \\
\hline 硫 黄 郕 & $168(9.8)$ & $57(7.8)$ & $26(5.3)$ \\
\hline 水 銀 郕 & $11(0.6)$ & - & - \\
\hline 他 & 364 (21.3) & $172(28.4)$ & $56(11.4)$ \\
\hline 明 & $217(12.7)$ & $39(5.3)$ & $29(5.9)$ \\
\hline म 1 & $7(100.0)$ & $742(100.0)$ & $491(100.0)$ \\
\hline
\end{tabular}


ラコートを「特定毒物」にすることなどを折りこんだ 総会決議を採択し，その使用規制を求める声明を出し， 関係諸機関への働きかけなども行なった。

他方，メーカ一側は，行政官庁による「特定毒物」 指定をさけ, 中毒発生の低減をはかるために, パラュー ト $24 \%$ 入りの液剤製造をやめ, 1986年 7 月からは、か わりにパラコート $5 \%$, ジクワット（ダイコート） $7 \%$ の複合液剂(プリグロックス $\mathrm{L}$ ，マイゼット)に切り替 えることによってこれに対処した。

したがって, 農薬中毒臨床例全国調査の報告症例も， 1986年 7 月以降はこれらの新剂による中毒例がしだい に報告されるようになり，とくに死亡例に関しては， プリグロックス Lやマイゼットによるウェイトが漸 次大きくなってきている。しかし，パラコートの濃度 は低くなっても多量に领用すれば同様に致死的である ことは, 注目する必要がある。因みに, 鹿児島大学附 属病院救急部の調査では, 以前のパラコート剂の中毒 症例33名のうち救命された者は 9 名 $(27.3 \%)$ である のに対して, 新剂服用の 7 名の救命率は 2 名 $(28.6 \%)$ であり,両者の間には皃とんど差が認められていない。

このような農薬中毒による死亡事故を減少させるた めには，どのような対策が必要かを研究するために， 佐藤らは茨城県の県南地域に打ける農薬中毒の実態調 查を行ない, 農薬中毒による死亡者の約 $99 \%$ \%゙パラ コート系除草剂による死亡であることを明らかにし， 急性農薬中毒対策は即パラコート中毒対策であるとい う成績を得ている。因みに中毒原因をみると，大部分

表 6. パラコート中毒死亡の概況（佐藤・他）

\begin{tabular}{|c|c|c|c|c|c|}
\hline 中毒の種類 & 症例数 & 生存数 & 死亡数 & 不明 & 死亡率 \\
\hline パラコート剤 & 124 & 20 & 95 & 9 & $82.6 \%$ \\
\hline 有機燐剤 & 20 & 19 & 1 & 0 & $5.0 \%$ \\
\hline \multicolumn{2}{|c|}{$\mathrm{N}=144($ 令 $81 \cdot$ 우 63$)$} & \multicolumn{4}{|c|}{ 平均年令 $43.4 \pm 16$ 才 $(\mathrm{Mean} \pm \mathrm{SD})$} \\
\hline \multirow{2}{*}{$\begin{array}{c}\text { 自 殺 } \\
113\end{array}$} & 事 故 & \multirow{2}{*}{\multicolumn{2}{|c|}{ 来院までの時間 }} & \multicolumn{2}{|c|}{ 死亡までの時間 } \\
\hline & 11 & & & \multicolumn{2}{|c|}{$54.1 \pm 12.9(\mathrm{~h})$} \\
\hline
\end{tabular}

表 7. パラコート中毒急性期死亡を予測しうる 緊急検查項目 (佐藤・他)

1. 尿中パラコート強陽性

2. 血清クレアチニン上昇 (平均 $2.0 \mathrm{mg} / \ell$ )

3. 低カリウム血症 (平均 $3.4 \mathrm{mEq} / \ell$ )

4. 代謝性アシドーシス (平均 $\mathrm{HCO}_{3}^{-} 18 \mathrm{mEq} / \ell$ )

(48時間以内に死亡する可能性大のもの)
が自殺であるが，さらにパラコート剤と有機燐剤によ る死亡率を比較してみると, 両者に著しい差異が認め られる(表 6 )。

また佐藤らは, 来院した農薬中毒症例を解析して, パラコート剂によって48時間以内に死亡する急性期死 亡を予測しらる緊急検査項目を検討して，尿中パラ コート強陽性などの検査の有用性を明らかにしている (表 7 )。

さらに，実際にパラコート系除草剂を使用している 一般農家を対象にして, パラコート系除草剤の保管状 況等について調査し, 日常的に積極的に啓蒙活動を推 進して行くことの重要性を明らかにした（表 8 )。なお 農薬を用いた自殺防止については，使用する危険性の あるヒトの mental healthの面からの適確な対応策の 検討も, 今後の重要な課題と思われる。

(3) パラコート剂中毒患者の解明と農薬曝露と疾病受 療率等との関連の調査

寺中らは, 富山県における農薬中毒実態調査と, 農 薬の慢性生体影響に関する疫学的調查を行なった。農 薬中毒実態調査では, 富山県全県の内科, 外科, 小児 科，皮膚科，眼科を標榜する診療所を対象として，3 年間に拈ける農薬中毒事例について検討した。その結 果, 最も多かったパラコート中毒患者では, 中毒の原 因は90\%近くが自殺であり, 患者の家業は兼業農家, 患者の職業は非農業の比率が比較的高いことなどが分 かった。また，服毒量と救命率との関係をみると，他 の諸家の報告とほぼ同様で, $15 \mathrm{ml}$ 以下では比較的救 命率が高いものの, これを上回ると救命率は著しく低

表 8．パラコート系農薬の保管と中毒事故に 関する調査 $($ 佐藤・他) $(\mathrm{N}=193)$

\begin{tabular}{lcl}
\hline 農薬の保管状況 & & \\
\hline すぐ手の届くところ & 19 名 & $(74.6 \%)$ \\
納屋・物置など & 125 & \\
鍵のかかった保管庫 & 49 & $(25.4 \%)$ \\
\hline 現在の保管状況で事故が起きる可能性があるか \\
\hline 絶対起きない & 119 名 & $(61.7 \%)$ \\
起きるかも知れない & 33 & \\
わからない & $41)$ & $(38.3 \%)$ \\
\hline 身近で起きた中毒事故を知っている農家 & \\
\hline 知っている & 53 名 & $(27.5 \%)$ \\
[保管方法の変更で事故は防げた & 30 & $(57 \%)$ \\
事故は防げなかった & 23 & $(43 \%)$ \\
知らない & 140 & $(72.5 \%)$ \\
\hline
\end{tabular}


くなることが分かった(表 9 )。さらにパラコート中毒 の初期治療の実態について種々検討し，その問題点を 明らかにした（表10）。

農薬の健康影響については, 個別の農薬の急性毒性, 亜急性毒性に関する報告は多数みられるが，その慢性 的影響についての研究は，きわめて乏しいのが現状で ある。そこで渡辺らは, 農薬の曝露と健康への慢性的 影響を知る目的で, 農薬散布者と非散布者との間で受 療状況，既往疾患，拈よび死亡原因について差異があ るか否かの比較検討を行なった。調査対象者は，水田 地帯の稲作農家 252 世帯の 1,081 人之昭和 40 年以降死亡 した 161 人である。この際, 農薬の人体影響を評価する 場合には，農薬輁露量を数量化することが必要となる が，これを農薬散布年数，年間散布回数，1回あたり の散布時間, 作業内容, 農薬の毒性度によってスコア 化して検討した(表11)。その結果, 農薬散布者の受療 率は非散布者より有意に高いといら成績を得ている。 また死亡原因について，全死亡中の悪性新生物による 死亡割合は, 農薬非散布者に比べて農薬散布者は有意

表 9.パラコート中毒患者に関する調査 (寺中・他)

\begin{tabular}{crc}
\hline 中毒の原因 & & $(\%)$ \\
\hline 自 殺 & 32 & $(86)$ \\
誤 飲 & 4 & $(11)$ \\
散布中の事故 & 1 & $(3)$ \\
\hline 患者の家業 & & \\
\hline 専業農家 & 2 & $(5)$ \\
兼業農家 & 16 & $(43)$ \\
非農家 & 12 & $(32)$ \\
不 明 & 7 & $(19)$ \\
\hline 患者の職業 & & \\
\hline 農 業 & 6 & $(16)$ \\
非農業 & 22 & $(59)$ \\
無 職 & 2 & $(5)$ \\
不 明 & 7 & $(19)$ \\
\hline
\end{tabular}

服毒量と救命率の関係

[死亡率 : $30 / 37(81 \%)$ ]

\begin{tabular}{cccc}
\hline \multicolumn{1}{c}{ 服毒量 } & 人 数 & 生存者 & 救命率 \\
\hline $15 \mathrm{~m} \ell$ 以下 & 8 & 7 & $88 \%$ \\
$\sim 20 \mathrm{~m} \ell$ & 5 & 0 & 0 \\
$\sim 50 \mathrm{~m} \ell$ & 5 & 0 & 0 \\
$\sim 500 \mathrm{~m} \ell$ & 12 & 0 & 0 \\
\hline 計 & 30 & 7 & 23
\end{tabular}

に高いことを明らかにしている（表12）。

農薬のなかには, IARCのモノグラフ（1987）などで も示されているごとく，ヒトに悪性新生物を発生する ことが疑われている農薬が種々あり, 渡辺らの成績は, かかる農薬の慢性的な影響を疑わせるものであり，今 後さらに詳細な検討が期待される。

また，農薬散布者におけるその他の慢性中毒の発症 については，近年，国内的にも国際的にも若干の報告 はされてはいるものの, なお未解明の部分が多く，そ の実態の解明は，これからの大きな課題となっている。

\section{2. 農業化学物質の人体残留の経年的推移と 人体影響に関する研究}

有機塩素系農薬は，かつてDDT，BHCやドリン剂 が殺虫剂として多量に使われていた。しかし，その後 これらが生物学的半減期がきわめて長く，その蓄積性

表10. パラコート中毒の初期治療の実態 (寺中・他)

1. 救急病院受診までの時間の長さ

診療所受診経由後救急病院へ来るケースは少量 服用でも死亡しやすい。

2. 年令および服毒量の無尿（腎不全）発現に及ぼす 影響

少量服毒例でも60才を超えると腎不全発症が極 端に早くなる。

3. 血液潅流 (DHP) の実施状況

早期開始と徹底した腸洗浄・強制利尿が不可欠 である。

4.ステロイド療法 (パルス療法) の実施状況 完全実施者は少ないが、救命の可能性あり。

表11. 農薬曝露の数量化 (渡辺 ·他)

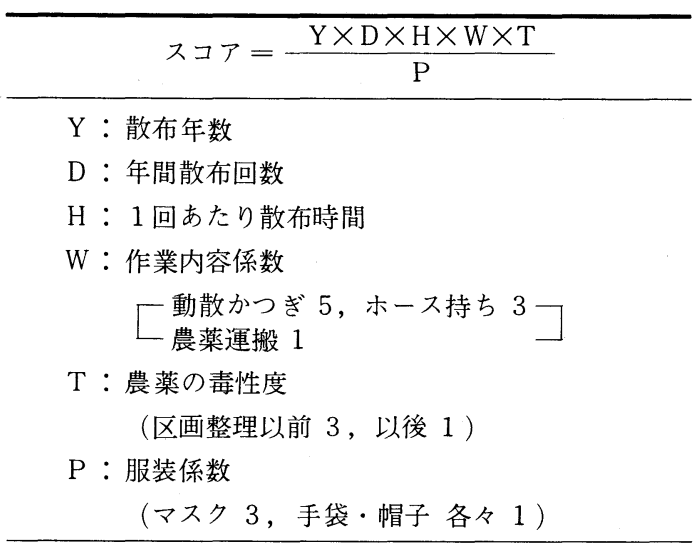


や悪性新生物など慢性中毒発生への関与の危険性が指 摘されるようになり，その使用が規制された。しかし

表12. 農薬曝露の受療率・悪性新生物死亡 への影響（渡辺・他）

\section{受療率 (年令訂正)}

農薬散布非経験者 $(n=146)$

稲作農薬散布経験者 $(\mathrm{n}=177)$

$$
\left.\begin{array}{l}
20.1 \% \\
30.8 \%
\end{array}\right] p<0.05
$$

全死亡中の悪性新生物の死亡割合 (年令訂正)

$\left.\begin{array}{ll}\text { 農薬散布歴なし }(n=156) & 0.209 \\ \text { 農薬散布歴あり }(n=76) & 0.445\end{array}\right] p<0.02$
これらの人体残留とその影響がいかなる現状にあるか は問題である。

（1）有機塩素系化合物（DDT，BHCなど）の母乳・脂 肪組織等への残留

菅谷・佐々木らは，有機塩素系農薬（BHC，DDT， dieldrinなど）による人体污染のモニタリングをとト 脂肪組織, 血液, 母乳などを試料として実施し， 1988 年までの 18 年間に約 1300 件を分析している。 $\beta-B H C$, $\mathrm{p}, \mathrm{p}$-DDE の両物質は, ほとんどの試料より検出され， 散布農薬, 特に有機塩素系化合物による人体および環 境污染が,かなり長期間持続することが示されている。

表13. 母乳中の有機塩素系化合物濃度の国際比較 (松下) 全乳中 (単位：ppm)

\begin{tabular}{|c|c|c|c|c|c|c|c|c|}
\hline （地区） & 検体数 & $\beta$-BHC & $\begin{array}{l}\text { total } \\
\text { BHC }\end{array}$ & $\begin{array}{l}\text { p, p'- } \\
\text { DDE }\end{array}$ & $\begin{array}{l}\mathrm{p}, \mathrm{p}^{\prime}- \\
\text { DDT }\end{array}$ & $\begin{array}{l}\text { total } \\
\text { DDT }\end{array}$ & Dieldrin & 報告者 （年) \\
\hline 本（秋田県） & 24 & 0.0139 & - & 0.0128 & 0.0007 & 0.0135 & 0.0007 & 菅谷・他（1986） \\
\hline " & 37 & 0.0217 & - & 0.0244 & 0.0016 & 0.0258 & 0.0003 & (1987) \\
\hline " & 27 & 0.021 & - & 0.026 & 0.001 & 0.027 & 0.0008 & $(1988)$ \\
\hline スペイン (マドリッド) & 20 & - & - & 0.17 & 0.083 & - & 0.003 & Baluja et al. (1982) \\
\hline フィンランド (ヘルシンキ) & 50 & - & 0.0023 & 0.030 & 0.0012 & 0.031 & - & Wickstrom et al. (1983) \\
\hline オーストラリア (パース) & 14 & - & 0.001 & - & - & 0.042 & 0.013 & Stacey et al. (1985) \\
\hline イラク (バグダッド) & 50 & 0.021 & - & 0.068 & 0.022 & - & 0.030 & Al-Omar et al. (1985) \\
\hline ユーゴスラビア(クロアチア) & 50 & 0.011 & - & 0.067 & $0.0073^{*}$ & - & - & Krauthacker et al. (1986) \\
\hline カナダ 「 土着人 & 18 & 0.0001 & - & 0.0142 & 0.0011 & - & 0.0004 & \multirow[t]{2}{*}{ Davies et al. (1987) } \\
\hline L一般人 & & 0.0002 & - & 0.0341 & 0.0030 & - & 0.0005 & \\
\hline インド (アーメババード) & 50 & 0.205 & - & 0.244 & 0.053 & - & - & Jani et al. (1988) \\
\hline$" \quad($ デリー) & 60 & - & - & 0.176 & - & - & - & Zaidi et al. (1989) \\
\hline
\end{tabular}

* 検体数に異同あり

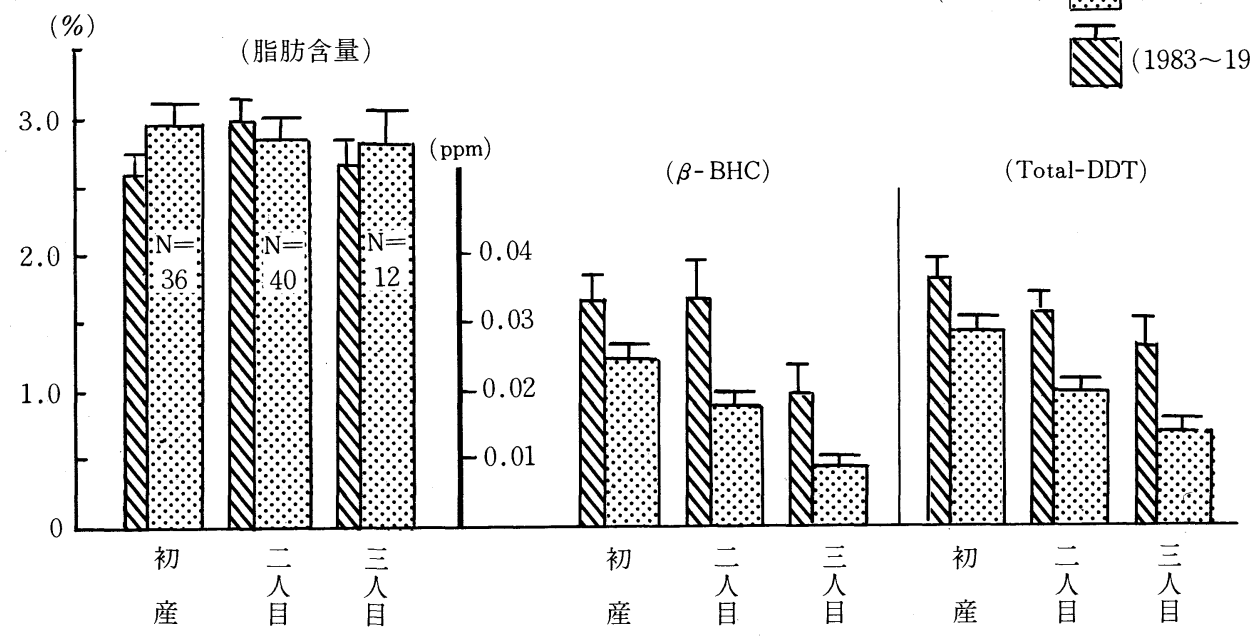

図 1. 出産回数と母乳中有機塩素系化合物残留量の関係 (佐々木・他) 
母乳中の残留量の測定では, 諸外国とほ湆類似した 成績を示し(表13)，これを昭和46年度以降の年次推移 でみると，その使用規制によって， $\beta$-BHC, total DDT ともにその平均値は約 4 分の 1 亿減少してい る。このような有機塩素系化合物の母乳中の濃度を, 出産回数との関係でみると, 初産母乳中の $\beta-\mathrm{BHC}$, total DDT の值の方が 2 人目以降の母乳より高い傾 向が認められる(図 1 )。各個人別に母乳中の有機塩素 系化合物の濃度と血液中の濃度との相関をとると, $\beta$ -BHC と DDT の主要代謝産物である $\mathrm{p}, \mathrm{p}$-DDE のい ずれも母乳中と血液中の濃度との間に高い相関関係が 認められる(図 2 )。このように有機塩素系化合物の人 体污染指標の試料として母乳を用いることは，きわめ て有用である。

一般にわが国では, 有機塩素剤の使用時では, 母乳 中のその濃度は使用量に相関した地域差として認めら
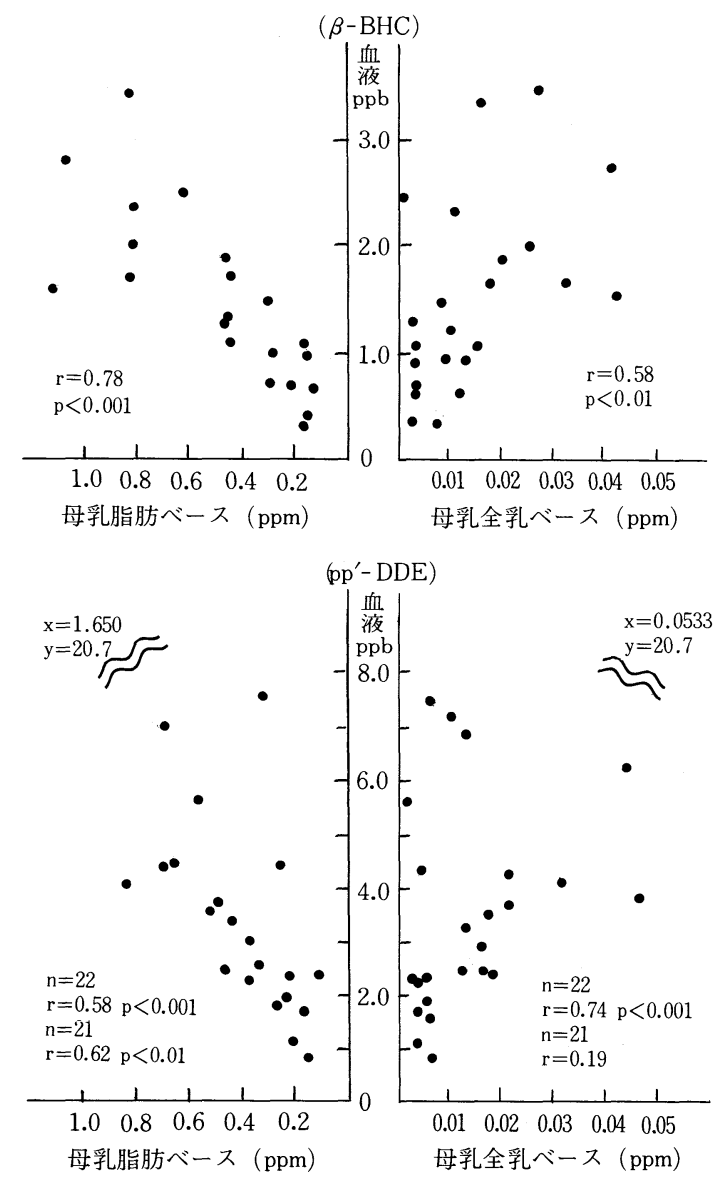

図 2.母乳中と血液中の有機塩素化合物の 残留量の関係 (佐々木・他)
れ，使用中止後は，食物連鎖を介した魚介類拱食量と の関連が強く, 血中濃度は体脂肪中の濃度と高い相関 が認められる。

つぎに河西・浅沼らは，BHC，DDTなどの有機塩素 剤の人体内残留の経年的な推移をみるために，入院患 者の手術時あるいは病理解剖時に, 皮下脂肪の提供を 受け，農薬残留量について調査をした。まず，1971年 からの年次推移をみると, 以前はかなり高い時期も あったが, 近年は total DDT, BHC, dieldrin ともに しだいに減少傾向が認められる。しかし最近は，その 減少率がきわめて少なくなって扔り(図 3 ), 最近のわ が国に括ける体脂肪中の成績と諸外国の成績との間に は，あまり顕著な傾向は認められない（表14）。

従来, 有機塩素系化合物の体脂肪中の残留量と疾病 との関連については, 癌患者に打いて高い濃度を示す といら報告もあるが，河西らの今回の成績では，癌疾 患群とその他の疾患群との間には有意差を認めていな い。

上田らは，南九州地方に抢ける有機塩素系農薬およ びその関連物質の人体残留の経年的推移を, 血清中掠 よび尿中濃度から追跡調査して, 男女の性差や農業従 事者と非農業従事者の間などに種々の差異を認めてい る(表15)。むた各個人別に測定した各種有機塩素系化 合物の血清中抢よび尿中濃度の相関関係をみると, 血 清 $\gamma$ - $\mathrm{BHC}$ と $\beta$ - $\mathrm{BHC}$ 抗ょび尿中 PCP, 血清中 dicofol (ケルセン) と p, p'-DDT および尿中 PCP な ぞの間に高い相関が認められるなど，各合成農薬中に 含まれる関連の不純物との関係からも, 興味深い成績 が得られている。

以上のよらな成績と内外の文献を参考にすると，有 機塩素系化合物の人体内蓄積量とその多寡に関与する

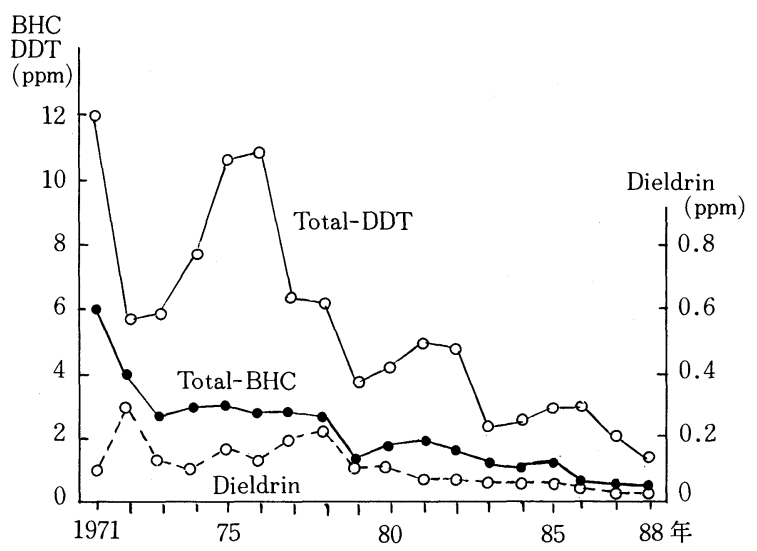

図 3.人体脂肪中有機塩素剂残留量の年次 推移 (河西・他) 
因子については，一般的な傾向として，まず男子は女 子ょり高濃度であり，これは脂肪が多い動物性食品の 撕食量や体脂肪の多寡, 性ホルモンへの代謝の影響な どで説明づけられ，また高令者の方が若年令者より一 般に高濃度なのは曝露機会の長さで，さらに，癌患者 群の方がその他の疾患群より高濃度残留していること については, その発癌との関与が疑われる一方, 癌患 者に拈ける体脂肪の減少により蓄積濃度の相対的増加 が生ずるるのと指摘されている。最近, Morganらは, コーホート研究によって個々人の血清中の有機塩素系 農薬の濃度と死亡率, 疾病罹患率との関連を調べ, 血 清中有機塩素系農薬の濃度が高値を示した群では, 高 血圧症, 動脈硬化性心血管疾患, 糖尿病との間に相関
がみられたと報告している。今後，実験成績から指摘 されている悪性新生物との関係を含めて, 疫学的にも 体系的に追及されることが期待される。

（2）クロルデンの体内残留と代替剤の人体影響

有機塩素系殺虫剤であるクロルデンは, わが国では, 主として白蟻駆除郕として用いられてきたが，近年ク ロルデンによる生態系や人体への污染の実態が明らか になるに伴い，1986年 9 月17日に化審法で「特定化学 物質」に指定され，その製造販売使用が中止された。 クロルデン曝露によるヒトの健康障害に関しては, こ れをでに事故による急性中毒の症例については報告さ れているものの, 慢性毒性については, クロルデンの 製造工場の従業員を対象とした若干の報告があるのに

表14. 体脂肪中の有機塩素系化合物濃度の国際比較 (松下)

(単位 $: \mathrm{ppm}$, 脂肪ベース)

\begin{tabular}{|c|c|c|c|c|c|c|c|c|}
\hline 国（地区） & 検体数 & $\beta-\mathrm{BHC}$ & $\begin{array}{l}\text { total } \\
\text { BHC }\end{array}$ & $\begin{array}{l}\text { p, p'- } \\
\text { DDE }\end{array}$ & $\begin{array}{l}\mathrm{p}, \mathrm{p}- \\
\text { DDT }\end{array}$ & $\begin{array}{l}\text { total } \\
\text { DDT }\end{array}$ & Dieldrin & 報告者 \\
\hline 日本 (秋田県) 死亡者 & 24 & 1.1709 & - & 3.0717 & 0.1152 & 3.1868 & 0.0547 & 菅谷・他（1986） \\
\hline " & 21 & 1.2574 & - & 2.7462 & 0.2399 & 2.9860 & 0.0455 & " (1987) \\
\hline 手術患者 & 30 & 1.468 & - & 2.998 & 0.214 & 3.212 & 0.042 & " (1988) \\
\hline \multirow[t]{2}{*}{ 日本 (長野県) 死亡者 } & 70 & 0.570 & 0.587 & 1.910 & 0.107 & 2.055 & 0.028 & 河西·他 (1986) \\
\hline & 60 & 0.418 & 0.443 & 1.254 & 0.083 & 1.344 & 0.027 & " (1987) \\
\hline \multirow[t]{2}{*}{ 日本（愛媛県） } & 46 & - & 3.77 & - & - & 4.04 & - & \multirow[t]{2}{*}{ Mori et al. (1983) } \\
\hline & 46 & - & 3.52 & - & - & 3.63 & - & \\
\hline カナダ (ケベック・他) & 99 & 0.151 & - & 1.721 & 0.311 & 2.064 & 0.049 & Mes et al. (1987) \\
\hline アメリカ合衆国 一令 & 12 & - & - & 4.866 & - & - & - & Ansari et al. (1986) \\
\hline \multirow{2}{*}{$\begin{array}{l}\text { (テキサス) Lo } \\
\text { イタリア (シエナ) }\end{array}$} & 12 & - & - & 2.734 & - & - & - & \\
\hline & 26 & - & - & 7.35 & 0.83 & - & - & Focardi et al. (1986) \\
\hline トルコ (アンカラ) & 48 & 1.52 & 1.72 & 5.83 & 0.62 & 7.12 & - & Karakaya et al. (1987) \\
\hline オーストラリア (シドニー) & 290 & - & - & - & - & 3.72 & 0.13 & Ahmad et al. (1988) \\
\hline スペイン (アグラリア) & 87 & 3.06 & - & 6.27 & 1.50 & - & 0.072 & Camps et al. (1989) \\
\hline
\end{tabular}

表15. 性別農業非農者別血清中及び尿中有機塩素系化合物の残留量 (上田・他)

(単位：ppb)

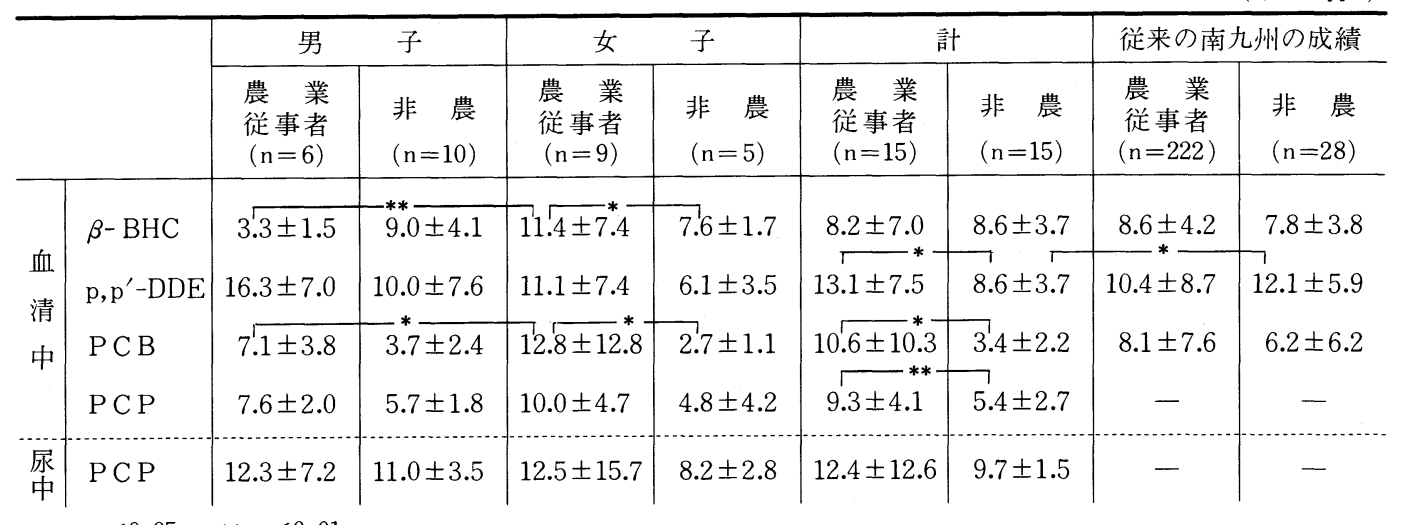

$* \mathrm{p}<0.05, \quad * * \mathrm{p}<0.01$ 
1068

過ぎない。

高宮・内田らは，クロルデンを使用した白蟻防除作 業者について, 血液学拉よび血液生化学的視点から七 卜の体内残留による慢性影響を，とくに腎機能に焦点 をあてて調査した。その結果，血液検查では末梢血に 白血球増多を認めるものが多く, 臨床生化学検査では,

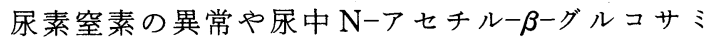
ダーゼや $\alpha_{1}-$ および $\beta_{2}-$ ミクログロブリンの排泄増加 など，以前にStohlmanによって示唆された腎近位尿 細管障害を疑わせる者が一部にみられたものの，ク口 ルデン濃度との有意な相関関係は認められなかった。 つぎに，クロルデンの体内残留による中枢神経系への 影響について, 脳波拈よび大脳誘発電位 $(\mathrm{P}-300)$ の検 査を実施し, 脳波検査の視覚的判定では正常範囲の判 定であったが，大脳誘発電位 (P-300) では潜時遅延傾 向が認められ，大脳の認知機能障害が疑われた。

またクロルデンの体内残留性について，クロルデン の使用中止措置後の血液中残留の推移を継続して調査 した。中止以前にあたる1986年 2 月のレベルを基準に とると, 3 種類のクロルデン関連化合物について, 減 衰傾向は認められず，概して横這いであり，またク口 ルデン関連化合物の残留量の変動と $\mathrm{p}, \mathrm{p}-\mathrm{DDE}$ 拈よ

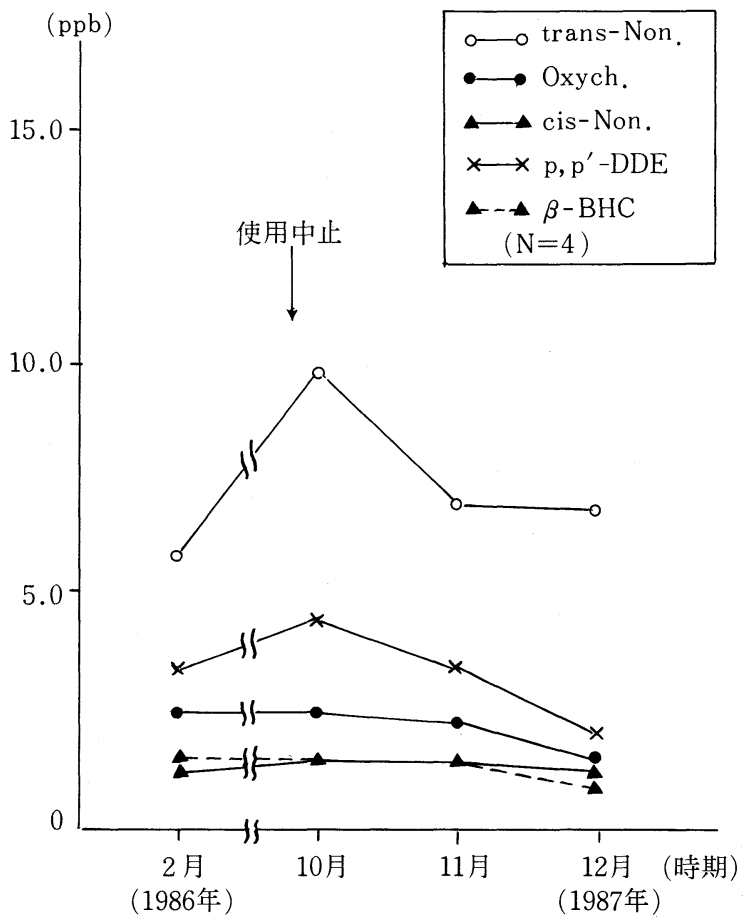

図 4.クロルデン関連化合物の血漿中残留量 の推移 (高宮・他)
び $\beta-\mathrm{BHC}$ のそれが同様で，ほぼ平行に推移する傾向 がみられた（図 4 )。

クロルデンの使用禁止後，その代替剂としては，ク ロルピリホス（ダーズバン）のような有機燐系殺蛳 が主として用いられている。この有機燐系農薬の曝露 の影響について，一般に指標として用いられている血 液 $\mathrm{ChE}$ 活性の低下を, 白蟻防除事業所の作業者で調査 したところ, 血漿 $\mathrm{ChE}$ 活性の異常低下者が高率に認め られこれに対して赤血球のアセチル ChE 活性では, 異常出現率が低く，この原因については，現在使用さ れている有機燐剤クロルピリホスに対して，アセチル $\mathrm{ChE}$ の感受性がプソイド ChE に比べて低いためと考 えている。

いずれにせよ，クロルデンの代替剤による健康影響 については，今後，さらに十分検討する必要があると 思われる。

\section{3．農業化学物質の生体に及ぼす慢性的 影響に関する実験的研究}

既述のごとく，農薬の慢性的影響に関しては，なお 十分な知見が集積されるとはいい難い。そこで，若干 の農薬について検討した。

（1）農業化学物質中毒に拈ける各種生体条件の及ぼす 影響に関する研究

1)スプラサイド粉剤 (FD) の吸入曝露とビタミン $\mathrm{E}$, C 欠乏の影響

近年の農業の省力化・機械化に伴い, 多種類の農薬 製剂が普及してきて扔り，それらのなかには，散布時 に著しい浮遊粉塵の発生を伴うものもある。

フローダスト (FD) 剂は, 平均粒径 $2 \sim 3 \mu \mathrm{m}$ の微 小粒子からなり，拡散性と浮遊性に優れているため， 散布時の省力化には優れた農薬製剂といえる。しかし， 大部分の農薬粒子が $10 \mu \mathrm{m}$ 以下の浮遊粒子状物質で あるため, 高濃度曝露の際は, 粒子自体の吸入による 影響之, 浮遊粒子状物質中の農薬成分による影響の両 方からの検討が必要と考えられる。そこで浅沼・安藤 らは, 粉塵曝露チャンバーを用い, FD 剂の経気道曝露 の影響について吸入曝露実験を行なった。用いた農薬 は微小粒子の農薬スプラサイド(DMTP)FDで，動物

表16. 害虫（白蟻）駆除作業者の血液コリン エステラーゼ (ch-E) 活性値低下 (高宮・他)

血 漿 $\mathrm{Ch}-\mathrm{E}$ 活性低下者 $14 / 21 \quad(67 \%)$ 赤血球 $\mathrm{Ch}-\mathrm{E}$ 活性低下者 $4 / 21 \quad(19 \%)$

(有機燐剤クロルピリフォス使用) 
は Hartley 系モルモットを用い，1日 8 時間，1 日， 3 日，7 日間それぞれ曝露した。

浮遊粒子状農薬に曝露された動物は, 肺胞マク口 ファージと肺胞上皮細胞内にかなりの量の粒子を保持 し, また粒子の吸入後, 肺胞上皮細胞と毛細血管内皮 細胞に著しい障害が起こり, さらに肝細胞の空胞変性 などもみられた。このような高濃度の FD 剂を吸入し た場合のモルモットの生体影響の一つとして血清中の GOT 活性をみると, 曝露の初期に顕著な増加が観察 され，また血清中の $\mathrm{LDH}$ 活性も同様に曝露によって 著しく上昇した(図 5 )。つぎに肝臓, 腎臓における脂 質過酸化の促進と, 抗酸化酵素の障害との関連につい て検討したところ, スプラサイド FD 曝露は, 肝細胞に 抢ける過酸化脂質の生成を著しく促進し, この肝細胞 に抢ける過酸化脂質濃度の上昇は, 曝露の初期に上り 著しいことが分かった(図 6 )。つぎに抗酸化系酵素で あるグルタチオン・ペルオキシダーゼ活性をみると,

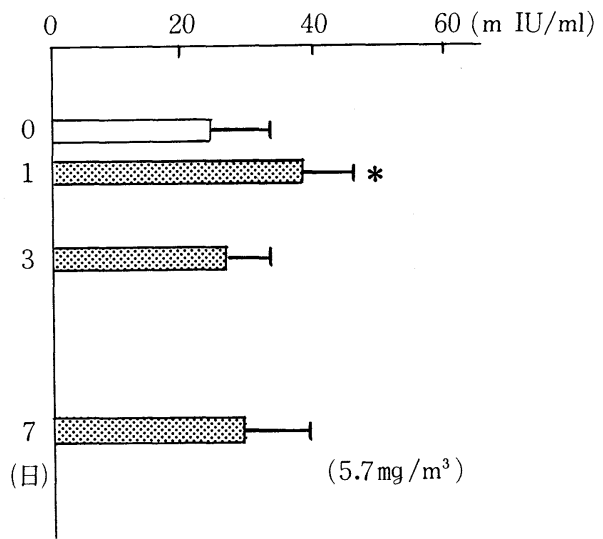

曝露初期に顕著な抑制が観察された。このことから， 抗酸化系酵素の活性阻害が脂質過酸化の増強を引き起 こし，ひいては肝細胞の変性を引き起こすと考兄られ た。

以上のような成績から，スプラサイド FD の経気道 曝露によるリスクの評価指標としては, 肺部の障害に 加光て脂質過酸化的障害に起因する肝機能障害, さら に心执よび腎等の障害が重要と考えられた。

さらに農薬の生体条件の変化による影響をうかがう ために, スプラサイド FD 曝露の際のビタミン $\mathrm{E}, \mathrm{C} の$ 欠乏の影響を検討したところ, ビタミン $\mathrm{E}, \mathrm{C}$ 欠乏モル モットでは, 農薬非曝露群でも脂質過酸化の生成促進 が認められた（図 7 )。

2)妊娠モルモットへのスプラサイド FD 吸入曝露の 影響

妊娠モルモットへのスプラサイドFD吸入曝露の影 響を，スプラサイド FDを 1 日 8 時間，1，3，7 日間

図 5.スプラサイド FD 吸入曝露時の血清中 GOT 活性 (安藤・他)

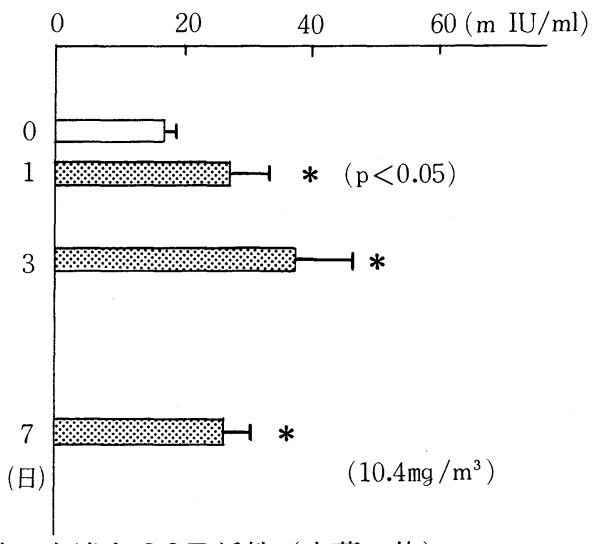

(n mole/g liver)
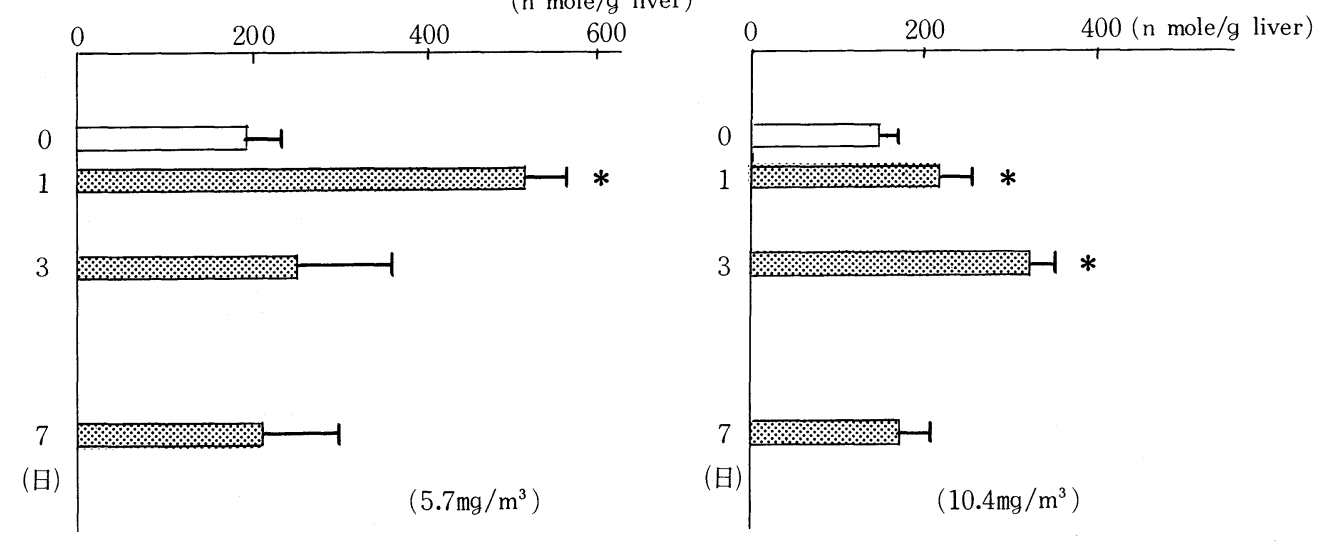

図 6. スプラサイド FD 吸入曝露時の肝内過酸化脂質濃度 (安藤・他) 
吸入曝露して調べると, 肝臓の脂質過酸化の増強, 血 清コレステロール含量の増大などが妊娠群でも認めら れ，妊娠の影響の大きさがうかがわれた（図 8 )。

(2) 除草剂の生体に及活す慢性的作用に関する研究

1)パラコートの慢性毒性に関する実験的研究

パラコート剂による急性中毒の発現については，か なり詳細に調べられているが，パラコート剤が慢性的 に摂取された場合の影響については，まだ十分解明さ れていない。散布作業者の長期間曝露や，散布後の污 染農作物摂取による曝露などを考旮た場合, 継続曝露 の研究は緊急に必要とされる。パラコート剤は慢性摂 取すると, 体内でラジカルや過酸化物の生成が長期間 続くことになり，それによる種々の障害が惹起される

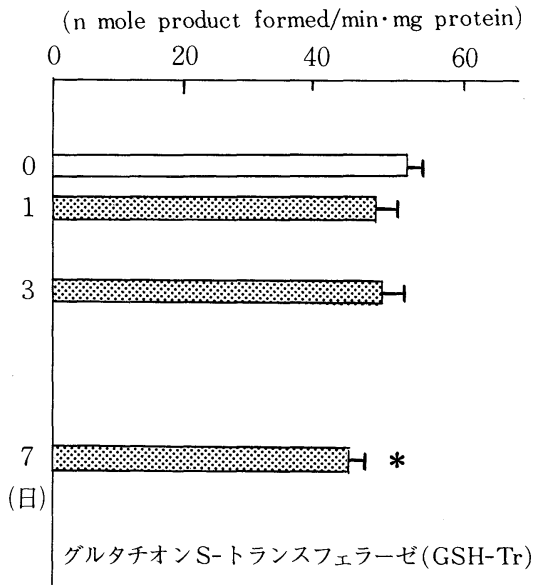

ことが予測される。

そこで安藤・浅沼らは，パラコート郕の慢性曝露に よりいかなる生体影響が生ずるかを明らかにするため に，ラットにパラコートを 1 日 $1,5,25 \mathrm{mg} / \mathrm{kg}, 1$ 年 2 力月間投与し，その慢性影響を検討した。

パラコート投与による組織学的変化としては，肺で はパラコート投与動物の $56 \%$ に纎維化が認められ，肺 緎維化の初発像と考光られるものでは, 胸膜の動静脈 吻合部に部分的変化がみられ，さらに病像の進行につ れて血管内皮の外周に浮腫とともに繊維増生がみら れ，無気肺を形成していた。また心臓では毛細血管， 細静脈の周辺に浮腫が強く, 心筋細胞の萎縮がみられ, 腎臓に扔いてもパラコート投与により，毛細血管，細

( $\mathrm{n}$ mole NADPH oxidized/min·mg protein)

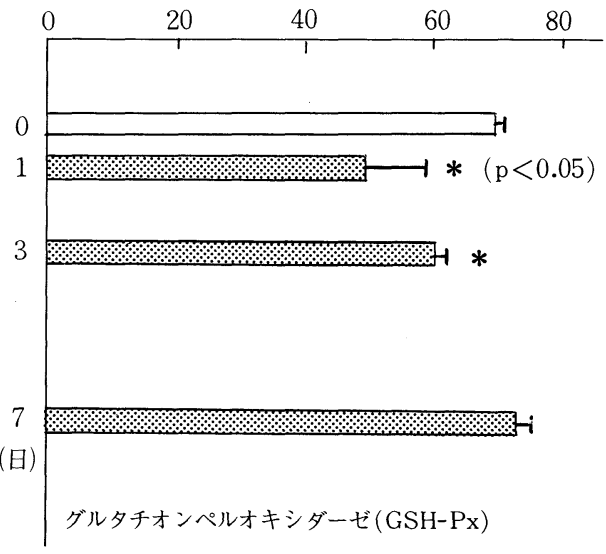

図 7.スプラサイド FD 吸入曝露時の肝細胞内 GSH 活性（安藤・他）

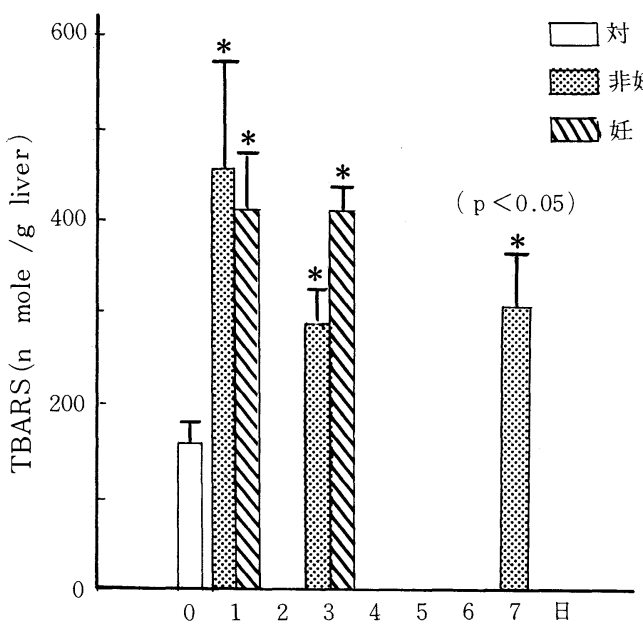

図 8．スプラサイド FD 吸入曝露時の妊娠 モルモットの肝内過酸化脂質濃度 (安藤・他)
T B A R S

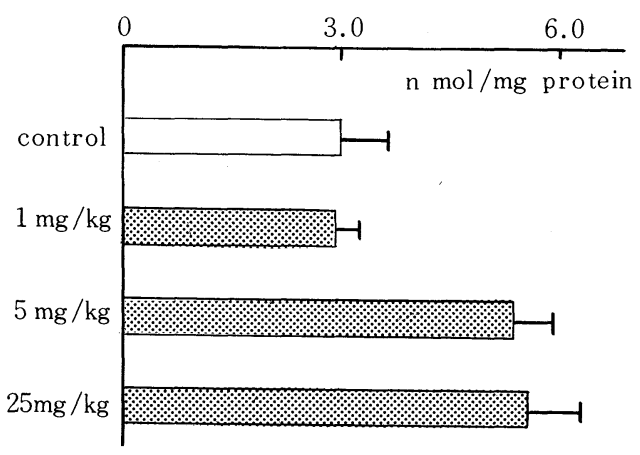

図 9.パラコート慢性曝露時の脳の過酸化 脂質濃度 (安藤・他)

(経口 1 年 2 力月) 


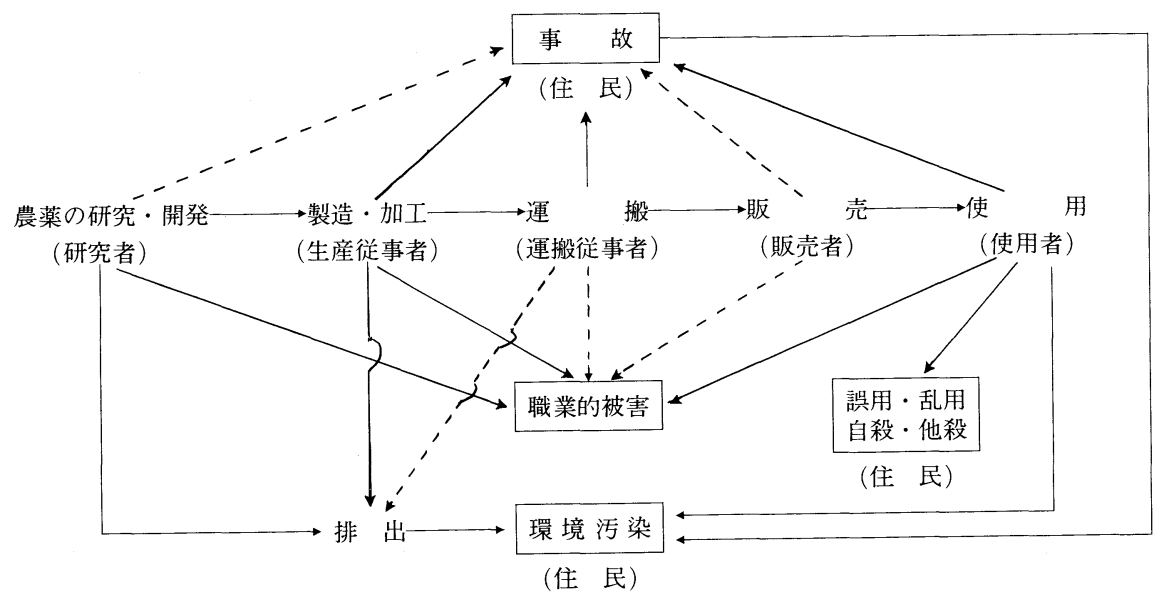

図10.人間社会における農薬の動態と健康被害の関係（松下）

静脈の周辺に浮腫が強くみられるなど, 種々の臟器に 組織化学的変化も認められた。血清生化学的にも，ア ルカリフォスファターゼ活性とクレアチニンの上昇, $\beta$-リポ蛋白, コレステロール, トリグリセライド, リ ン脂質の低下など顕著な変化が観察された。一方，パ ラコートの慢性曝露による注目すべき所見として，各 種の臓器において過酸化脂質の増加が観察され, 腎や 肝のほかに，脳に扔いてもパラコート投与により過酸 化脂質生成の増加が認められた（図 9 ）。

このようにパラコート剤は, 慢性曝露によって肝, 腎, 脳の諸藏器において過酸化脂質生成の増加が観察 され，とくに脳に打ける過酸化脂質の生成の増加が認 められることは，その生体影響を考劣ていくうえで重 大なことと考学られる。今後そのメカニズムの解明を 含めてさらに詳細な研究が必要である。

2) パラコートと各種薬物の相乗作用に関する研究 上記のごとく，パラコートの慢性毒性に関する動物 実験から，微量であっても長期にパラコートを摂取す れば，脳や腎臓に過酸化脂質濃度が上昇することが確 認されたことから，浅沼・佐々木らは，この過酸化が 他の薬物投与によって増強されるか否かを確認するた めに, 各種薬物との相乗作用について検討した。しか し，パラコートとアセフェート，ビタミン $\mathrm{E} な と ゙ 5$ 種 類の薬物の効果量をあわせて28日間投与しても，アセ フェート，フェノバルビタール，ビタミン E などの併 用時に一定の影響はみられたものの，いずれの薬剤に おいてもパラコートによる障害の緩和の明らかな所見 は認められなかった。

パラコートの人体への影響に関しては，その劇的な 急性毒性のみならず，慢性毒性として既述の障害のほ
表17．農薬の安全性保証が困難な理由（松下）

1．急性毒性の大小と慢性毒性の大小は必ずしも同じ 傾向ではない。

2.製品に含まれる不純物により毒性が影響されるこ とがある。

3. 使用環境中や生態系で分解・変質することにより 毒性が変化する。

(分解産物必ずしも原体より低毒性だとは限ら ない

4. 動物実験による人体への影響の予測には限界があ る。

$\left.\begin{array}{l}\text { (医薬品の臨床試験・副作用情報監視体制を参 } \\ \text { 照のこと }\end{array}\right)$

5. 混合使用や他の薬剤等との共存によって複合作用 が生ずることがある。

6. 他の環境因子などにより毒性の生じ方が影響され ることがある。

7. 個人差・体調などにより毒性の生じ方が異なる。

8. 使用環境・使用条件や防御体制などにより人 体影響に差異が生ずる。

$\left(\begin{array}{l}\text { 研究室内の研究だけでは実際の被害を予測す } \\ \text { ることは難しい }\end{array}\right)$

かパーキンソン病等との関連を指摘する報告などもあ り, 今後さらに詳細な研究が必要である。

以上が研究班の 3 年間の研究成績の主な内容である が, 詳細な研究成果や文献等は, 個々の学会誌等の論 文や研究報告書を参照されたい。

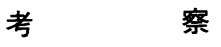

農業化学物質の人間の健康に及ぼす影響は, 社会に 
扣けるその研究開発から使用に至る広汎な一連の流れ の中で位置づけることができ，ある場合は職業性に， またある場合は環境污染等によってヒトの健康に影響 を及ぼすことになる(図10)。しかも農薬による生体影 響はきわめて多岐にわたり，急性的な影響による障害 のレベルは，いわば氷山の一角にすぎず，乙かも既述 のごとく、まだ多くの重要な部分が末解決のまま残さ れている。

農薬の危険性は，基本的には農薬の毒性，すなわち 農薬の持っている固有の性質によって規定されるが, ヒトに対する曝露濃度や曝露時間あるいは期間, すな わち農薬の使用方法や使用条件とも密接な関係があ る。この際, われわれは, まず農薬の安全性を保証す る課題がきわめて難しい問題だということを，十分念 頭に打く必要がある(表17)。例えば，医薬品開発の場 合には，単に動物実験のみならず，第 I 期から第III相 までの臨床試験を必ず行ない,さらにWHO を中心に した医薬品の副作用情報を組織的に収集する制度が確 立している。このことからも分かるように，化学物質 の人体への影響を動物実験だけで予測するには大きな 限界があることを認識する必要がある。また自然界で 一見分解しやすい農薬であっても，その分解産物は必 ずしも原体の農薬よりは低毒性物質であるとは限らな い。殺菌剂ダイホルタン (captafol)の分解産物による 重篤な皮膚障害の発生, 硫黄殺菌剂マンネブ・ジネブ
剂からの催腫痬性物質エチレンチオウレア (ETU) の 生成などがこの例である。

したがって，このような多様な性質を有する農業化 学物質の使用については, 慎重のうえにも慎重を期す という基本的な態度が必要である。また農薬開発から その使用にあたっては, 生態中毒学的な視点も含めて 行ならべきその毒性研究とともに，現場に適確な安全 使用技術の開発や衛生教育の徹底も重要であるのは言 うまでもない。そらした意味で, 日本農村医学会の社 会的な責任は大きく，農業従事者や農業改良普及員な ど現場の人達とはもちろんのこと，WHO など国際機 関等とも密接な連携をとりながら，学会としての社会 的な期待に応えてゆく必要があろら。

$$
\text { おわりに }
$$

以上，研究班活動の成績を中心にして農業生産活動 に扣ける化学物質の人体への影響とそれらに関する問 題点について概説した。農業化学物質は, 本来諸刃の 剣である。したがって農業生産活動の中で農薬を正し く位置づけ，その有用性と危険性に対して総合的な視 点で適確に対処してゆくことがきわめて重要である。

稿を終わるにあたり，発表の機会を与えていただいた下村尚一 学会長を始め, 若月俊一研究班長, 分担研究者や多数の共同研究 者に, 厚く御礼申し上げたい。

\title{
Studies on the Effects of Agricultural Chemicals on Humans
}

\author{
Toshio MATSUSHITA*
}

This is a review on the research work undertaken by the cooperative study group (chief: $\mathrm{T}$. Wakatsuki) from 1986 to 1988.

The results of many studies including clinical case study, epidemiological study and experimental study as well were presented and discussed.

*Department of Hygiene, Faculty of Medicine, Kagoshima University 